\title{
The Hereditary Transmission of Acquired Characters *
}

\author{
By Prof. J. B. S. Haldane, F.R.S.
}

" Enfin les efforts faits par le besoin pour obtenir des facultés nouvelles, se trouvant aidés du concours des circonstances favorables, créent avec le temps les organes nouveaux qui sont propres à ces facultés, et qu'ensuite un long emploi développe."

LAMARCK, Discours d'ouverture de l'an XI.

"Nil ideo quoniam natumst in corpore ut uti Possemus, sed quod natumst id procreat usum.' Lucretius, De Rerum Natura, iv. 834.

THE tendency of men, animals, and plants to resemble their parents has been known for some thousands of years, although it is only since the time of Mendel that it has been realised that this is only half, and not necessarily the most important half, of genetics. Given that principle, men naturally argued somewhat as follows: A fat pig generally has fatter children than a thin pig. If we fatten up this thin pig, his children will be fat. This is a straightforward argument, as good as most used in politics. But it is, as we shall see, fallacious. The difference between a fat and a thin pig may be due to two causes. The two pigs may be of the same breed, but have had a different diet; or they may be of different breeds, but have had the same diet. Finally, of course, both causes of difference, external and internal, may be operating. Now, those who, like Lamarck, believe in the hereditary transmission of all acquired characters, take the view that if fatness has been produced for some generations by the external cause of diet, it will later go on being produced by internal causes when the external cause is removed. There is nothing impossible in this supposition, but if we put it that way, its $a$ priori probability appears less.

As the result of experimental work, some of which I shall summarise, the majority of geneticists take the view that characters acquired as the result of external influences are rarely inherited, so rarely that the exceptions are of little importance either for the explanation of evolution or the practical problems of the breeder or eugenist.

Last year Prof. E. W. MacBride restated the case for Lamarckism in a discourse under the title of "Habit, the Driving Factor of Evolution". $\dagger$ Prof. MacBride's contributions to the science of embryology have been most distinguished, and his apparently heretical views on the historical process of evolution, for example, concerning the descent of the vertebrates from a common stock with the echinoderms, have been confirmed by subsequent work. But just as the best of historians may not be the best judge of the politics and economics of his own day, so an eminent student of the history of evolution may conceivably be mistaken as to its causes. These must be decided on by observing the

* Friday evening discourse delivered at the Royal Institution on A pril 22. (Since the lecture was written, I find that Prof. W. E. Agar has covered much of the same ground and anticipated many of my Australian Journal of Experimental Biology (1932),-J. B. S. H.)

+ NATURE, 127, 933, June 20, 1931 .

No. 3266 , VoL. 129] changes which actually occur in living organisms under controlled conditions.

I shall begin by giving an example of one of the rather rare cases where an acquired character is unquestionably inherited. If we cut off the growing point of a young tomato plant it produces new shoots. A few of these regenerated shoots are somewhat abnormal. The leaves are larger, and if these shoots are cut off and rooted, a new race of tomato is produced. It differs from the original stock in the following respects. The leaves are thicker, less dissected, and have more anthocyanin. The fruits are smaller but more numerous. The whole tempo of the plant is slower. It does not start growth so quickly, but continues for a longer time, and finally reaches a larger size. What is more, not only do the abnormal plants transmit the character by vegetative propagation, but if their flowers are self-fertilised the seedlings resemble the abnormal parents. They can only be crossed with the original type with great difficulty, and the hybrids are extremely sterile.

Now, if we examine a dividing nucleus of the ordinary tomato, we find 24 chromosomes. The abnormal type has 48 , or double this number. Such plants are called tetraploids, because they have four similar sets of chromosomes, instead of two as in normal tomatoes. We know that the chromosomes are responsible for most, if not all, of the heritable differences between different tomatoes. By our injury we have provoked a stable and self-perpetuating rearrangement of the physical basis of heredity. Where this is possible, acquired characters are inherited.

Induced tetraploidy has doubtless been of some importance in plant evolution, and possibly in animal evolution. But it does not produce very striking changes. Moreover, there is no suggestion that they are adaptive, that is to say, that the tetraploid plants are better off than the diploid in any way; in particular, they do not appear to resist mechanical injury any better. The importance of the Lamarckian hypothesis for evolution lies in the possibility that adaptive changes, such as undoubtedly occur in the life of an individual, are handed on to its offspring.

It is also worth noting that in this case the change is only found in the descendants of a particular cell the nucleus of which has failed to divide. It is not transmitted to other parts of the plant. Now, in the higher animals the cells which will form the future germ cells are cut off at an early stage from the rest of the body, and are care. fully shielded from change by a series of processes regulating the temperature and chemical composition of the blood going to them. This argument a ppealed to Weismann. But it does not apply to the higher plants, where the cells of any growing point may give rise to germ cells. In any event, it is not a very sound

¥ I must thank Dr. Sansome for permission to quote his unpublished observations. 
argument, even in higher animals, as the environment of the germ cells is not absolutely constant.

I will now cap my positive example with some negative ones. If plants or animals are inbred for many generations, they approximate to what is called a pure line. Within any such line, differences are not inherited. All members have the same hereditary make-up. The differences between them are due to environment, and are not handed on to the offspring, as appears from Table I. (from Johanssen). The progeny of the heaviest beans chosen within the line were no heavier than those of the lightest. Within such a line neither Lamarckian transformation nor Darwinian selection produces any measurable effect.

Exactly the same results were obtained by Wright within pure lines of guinea-pigs. The guinea-pigs born of old mothers had more white in their coats and fewer toes than the average, but their offspring did not resemble them in these respects. Clearly a transformation of a pure line would be a much more notable achievement than

TABLE I.

\begin{tabular}{|c|c|c|c|c|c|c|c|}
\hline \multirow{2}{*}{ Year. } & \multirow{2}{*}{$\begin{array}{l}\text { No. of } \\
\text { Beans. }\end{array}$} & \multicolumn{3}{|c|}{ Mean Weight of Parents. } & \multicolumn{3}{|c|}{ Mean Weight of Offispring. } \\
\hline & & Light. & Heavy. & $\begin{array}{l}\text { Differ- } \\
\text { ence. }\end{array}$ & Parent Light. & Parent Heavy. & Difference. \\
\hline $\begin{array}{l}1902 \\
1903 \\
1904 \\
1905 \\
1906 \\
1907\end{array}$ & $\begin{array}{l}145 \\
252 \\
711 \\
654 \\
384 \\
379\end{array}$ & $\begin{array}{l}600 \\
550 \\
500 \\
430 \\
460 \\
560\end{array}$ & $\begin{array}{l}700 \\
800 \\
870 \\
730 \\
840 \\
810\end{array}$ & $\begin{array}{l}100 \\
250 \\
370 \\
300 \\
380 \\
250\end{array}$ & $\begin{array}{l}631 \cdot 5 \pm 10.2 \\
751.9 \pm 10.1 \\
545.9 \pm 4.4 \\
635.5 \pm 5.6 \\
743.8 \pm 8 \cdot 1 \\
690.7 \pm 7.9\end{array}$ & $\begin{array}{l}648 \cdot 5 \pm 7 \cdot 6 \\
708 \cdot 8 \pm 8 \cdot 9 \\
566 \cdot 8 \pm 3 \cdot 6 \\
636 \cdot 4 \pm 4 \cdot 1 \\
730 \cdot 0 \pm 7 \cdot 2 \\
676 \cdot 6 \pm 7 \cdot 5\end{array}$ & $\begin{array}{l}+17.0 \pm 12.7 \\
-43.1 \pm 13.5 \\
+20.9 \pm 5.7 \\
+0.9 \pm 6.9 \\
-13.8 \pm 10.8 \\
-14.1 \pm 10.9\end{array}$ \\
\hline
\end{tabular}

After Johanssen. Weights in milligrammes.

be called an instinct, a tropism, or a reflex, according to taste. Now, it is a well-known fact that cave-dwelling animals are often blind and colourless. Payne bred Drosophila in darkness for 69 generations. After ten generations he believed that he had diminished their tendency to fly towards a light. But after 69 generations there was no change in colour or structure, and the effect on behaviour, as measured on 1000 flies, was negligible. The flies were given ten minutes or more to adapt themselves to light, and were then placed at one end of a dark tube nine inches long, the other end of which was illuminated. About a quarter of the flies did not react within a minute, and were 'counted out'. This proportion was not altered by breeding in darkness. On the other hand, the speed of reaction was very slightly increased. There is certainly no suggestion that the flies had lost the tendency to move towards light through disuse.

The alternative explanation of blindness in cave. dwellers is that animals suffering from hereditary blindness have no tendency to leave a cave, and hence their descendants populate it. It is inter. esting that a race of the same fly, selected on account of a peculiar body colour, does not move towards light, and might therefore remain in a cave where normal flies would tend to leave it.

We now turn to some of the experiments on which the neo-Lamarck-

anything done in a mixed population, because in the latter case selection is known to be effective, and it is up to the Lamarckian to prove that he has not exercised selection.

The two experiments which have lasted the greatest number of generations have both been performed on quickly breeding arthropods. Agar bred the little water-fleas Simocephalus and Daphnia for 101 and 79 generations respectively. These animals reproduce by parthenogenesis, under the conditions of Agar's experiment, the life-cycle being completed in a week or a little longer. They swim by means of their second antennæ. If one branch of these is cut off when the animal hatches, the feather-like setæ are usually, though not always, regenerated. It might have been expected that after a hundred generations the progeny of the operated animals might have shown an increased aptitude for regeneration. This was not the case. If anything, they regenerated very slightly worse than the controls, but the difference was not significant. Agar also tried the effect of selecting those animals which regenerated best. He got no effect at the end of forty generations. This was to be expected, as he worked with a clone, within which, as within a pure line, there are no heritable differences.

It might be hoped that better effects would be obtained where the character studied was of a more psychological kind. The fly Drosophila melanogaster generally moves towards a light. This may ian case is based. Except those of McDougall, which are in a class by themselves, none of these has been conducted on approximately pure lines. Since we know that in a mixed population selection is effective, we shall see whether this cannot account for the observed changes. I will therefore consider the experiments cited by Prof. MacBride.

Dürken worked with Pieris brassica, the cabbage white butterfly, the pupæ of which become green when the larvæ are kept under yellow, orange, or green glass. This discovery was not made, as MacBride states, by Dürken, but by Wood in 1867 , and very fully described by Poulton in 1887. In a typical experiment of Dürken's, 4 per cent of the pupæ reared in normal light were green, as were 63 per cent of those reared in orange light. Only the moths emerging from the green pupæ were bred from, and these gave 98 per cent green when the caterpillars were kept in orange light, and 48 per cent in normal daylight. Now, one cannot prove that Dürken had not observed the transmission of the effect of the light. But there is no evidence for this hypothesis. He had selected the green fraction of the pupæ, and naturally enough he got more greens in the next generation. Selection is generally quite effective except within a pure line, and there is not a shadow of evidence that Dürken observed anything but the effects of selection.

For comparison, let us study a more scientifically

No. 3266, VoL. 129] 
conducted experiment of the same kind, namely, the late Dr. Bateson's experiment (posthumously published from his notes by Sir Daniel Hall) on 'bolting' in sugar beets and mangolds. On an average, about 5 per cent of the plants in a field of sugar beets bolt, that is to say, they throw up a stem and set seed during their first year, so that the roots are denuded of sugar and worthless. The rest behave as biennials. Mangolds show a similar phenomenon. It was known that early sowing promotes bolting. Now, Bateson, we may assume, started out with the hypothesis that bolting may be due to internal or external causes. So, instead of sowing mangolds in the open in April, he sowed them under glass in December or January, and planted them out in April. Thus any plant with an inherent tendency to bolt was given the fullest opportunity to do so. Sutton's Prize Globe mangold gave only 2 bolters out of 390 when sown in April. But when sown in December, 8 out of 19 bolted. The 11 non-bolters were used for seed, and none of their progeny bolted, even when sown in January. However, some seedlings from this family were subjected to severe temptation to bolt by sowing in December. Ten out of 136 (a much smaller proportion) bolted ; but 213 of the progeny of the non-bolters refused to bolt when sown in January. In the case of sugar beet, the proportion of bolters was greater, and four generations were needed to eliminate the habit.
Bateson also made the converse experiment of trying to establish a race which always bolted. He did not get any appreciable increase of bolting when he selected the progeny of plants which had bolted as the result of early sowing. But by sowing seed of 12 plants out of 312 which had bolted when sown in April, he got 41 per cent of bolters. All this is entirely intelligible on the theory that bolting, in so far as it is an acquired character, is not inherited. If Dürken had bred from the pupæ which refused to turn green even in orange light, he would no doubt have been able to eliminate the tendency to turn green; and if he had bred from those which turn green in ordinary light, he would presumably have obtained a more striking change in the next generation than was actually found. In order to prove the Lamarckian theory, it would be necessary either to start with a pure line or not to practise selection. Harrison, who worked with the turnip white butterfly, Pieris rapa, which normally gives about 20 per cent of green pupæ, obtained more striking effects than Dürken, as he only appears to have eliminated 7 per cent in one generation and 5 per cent in the next, and yet obtained 31 pupæ, all green, in normal daylight. While Harrison's case is thus far stronger than Dürken's, it cannot be regarded as conclusive unless similar results are obtained without selection, either artificial or natural.

(To be continued.)

\section{The Transport Problem in the United States}

$\mathrm{I}^{\mathrm{N}}$ $\mathrm{N}$ the century and a half which has elapsed since the American steam-boat pioneers, Fitch and Rumsey, began their experiments on the Delaware and Potomac rivers, transport in the United States has undergone many remarkable changes. From the work of those pioneers, in the course of years, came a magnificent fleet of river steamers; her engineers next gave the country the most extensive railway system in the world; while to-day the automobiles are so numerous that there is one for every five of the population, and transport by air is making rapid progress.

America is what it is largely because of its transport, without which its prairies would still be uncultivated and its mines unexploited. One of the landmarks in the history of that transport was May 10, 1869, when the last spike-a golden one-was driven in the railway which connected the Atlantic coast with the shores of the Pacific. On that occasion Philadelphia rang the old Liberty Bell, New York fired a hundred guns, Buffalo sang "The Star-Spangled Banner", and there was even a thanksgiving service in Trinity. There then seemed no end to the benefits to be gained from the railways, which to-day, by the irony of fate, are faced almost with bankruptcy.

Like our own railway system, that of the United States was built up entirely by private enterprise, and the present position of the railways is much the same as our own; some think it is somewhat more complex. What that position is, and what remedies are suggested so that the railways can continue to fulfil their part in the national economy, are well stated in three contributions printed in the first issue for the current year of the Proceedings of the American Philosophical Society. The three papers are entitled: (1) "The Railroad Situation : Some Suggestions as to the Way Out"; (2) "A Way for the Railways to Keep Out after they are Out "; and (3) "Co-ordination as a 'Way-out' of the Transportation Crisis" - the respective authors of which are Dr. E. R. Johnson, Mr. A. B. Johnson, and Mr. G. L. Wilson. Of the three papers, the first is much the longest and gives a record of all the factors of the problem.

The United States railway system has some 250,000 miles of track, and the rolling stock includes about 67,000 locomotives, 57,000 passenger cars, and $2,500,000$ freight cars, the results of the development of a hundred years. The public roads include $3,000,000$ miles of highways, of which some 700,000 miles are surfaced and about 128,000 miles are mainly of concrete. About 50,000 miles of streets are constructed or rebuilt annually, the expenditure on which reaches $2,000,000$ dollars.

The number of automobiles of all kinds registered in the United States at the end of 1931 reached the astonishing figure of $23,042,840$, the result of thirty years' development; and the number of companies engaged in freight traffic services runs into thousands. There are no complete statistics of the freight carried by motor vehicles, but not only are 